\title{
Information and Communication Technology and Knowledge Management in Higher Education System
}

\author{
Mohammad Reza Sarmadi, ${ }^{1}$ Bahman Zandi, ${ }^{2}$ Ziba Nouri,, ${ }^{1, *}$ and Masoud Gholamali Lavasani ${ }^{3}$ \\ ${ }^{1}$ Department of Educational Sciences, Faculty of Educational Sciences, Payame Noor University, Tehran, IR Iran \\ ${ }^{2}$ Department of Linguistics, Faculty of Linguistics Payame Noor University, Tehran, IR Iran \\ ${ }^{3}$ Department of Educational Psychology and Counseling, Faculty of Psychology and Education, University of Tehran, Tehran, IR Iran \\ "Corresponding author: Ziba Nouri, Department of Educational Sciences, Faculty of Educational Sciences, Payame Noor University, Tehran, IR Iran. E-mail: \\ zi_nouri@yahoo.com
}

Received 2017 April 03; Accepted 2017 May 31.

\begin{abstract}
Given the importance of knowledge management at university, most scholars believe that the key to the success of knowledge management is the capacities information and communication technology provides in this field. Thus, the present article aims to identify effective factors of information and communication technology on knowledge management in higher education. Research methodology: this is a qualitative study conducted by content analysis and semi-structured interviews with academics from state universities in Tehran as well as objective sampling in the year 2016. Using an analysis of data resulting from semi-structured interviews and a review of research, background effective factors of optimal use of communication and information technology were identified. Then, they were classified into main and additional categories. Results from encoding and categorical content analysis suggest that hardware and software infrastructures, access to academic databases and electronic networks, access to new knowledge research, retrieval, storage, exchange and processing technologies, and mastery over related software are regarded as effective factors of information and communication technology on knowledge management in the higher education system. Each category covers several subsets. Conclusion: in order to apply the findings of the present research in practice, it is suggested that the establishment of knowledge management system approach be valued in academic environments.
\end{abstract}

Keywords: Knowledge Management, Information and Communication Technology, Education, Qualitative Research

\section{Introduction}

As we know, universities and research institutes constitute social academic communities that play a vital role in creating and transmitting scientific knowledge (1). Advanced development in the world of information technology has provided the necessary infrastructure to support the development of new organizational forms (2). Information and communication technologies can represent a source of competitive advantage for an organization (3). Knowledge management plays a key role in high education (4-7). Knowledge management (KM) is concerned with the processes or practices of creation, acquisition, capturing, sharing, and usage of knowledge, wherever it resides, to enhance learning and performance in organizations (8). Academics, as centers of knowledge production and spread, highly require knowledge management $(9,10)$. Informational technological changes have transformed universities and colleges; systematic information networks, knowledge, and sciences have provided opportunities for knowledge production, spread, and sharing with the help of information and communication technology (11). Knowledge is dynamic, since it is created in social interactions amongst individuals and organizations (12). Jashapara (13) states, knowledge management includes influential learning processes combined with knowledge creation, organization, and exchange. Proper use of technology and cultural atmosphere leads to incensed organizational intellectual capital and improved performance.

Jung et al. (14) defined knowledge management as the process of applying and providing skills and expertise in organizations which are supported by information technology. Most researchers believe that knowledge management is successful thanks to the capacities which information technology provides in the modern time (15). Information and communication technology (ICT) provides potential means for improving knowledge work productivity, for example, through helping knowledge workers perform certain routine (ie, non-value-adding) tasks faster and through supporting knowledge sharing among professionals (16-19). Modern technologies enable organizations to implement knowledge management system, store, and share unstructured information (20). They also facilitate the integration of disorganized knowledge so that most activities can be done in the shortest time (21).

Studies conducted on knowledge management divide 
it into tacit and explicit knowledge $(4,10)$. According to Nonaka and Takeuchi, tacit knowledge exists in the mind of individuals (12), while explicit knowledge is available in organizations and can be easily processed by computers, transferred electronically, and stored in databases. It is shared among individuals as an official and systematic manner very easily (22). The interdisciplinary nature of knowledge management had a big part in providing different views and epistemologies of knowledge management (23). These differences might result from informationbased, technology-based, and culture-based outlooks (24). Regarding when information-based outlook is dominant on the management level, two models have been developed for implementing the knowledge management system (19).

1- Network model in which communicative technologies and guidelines are used to link knowledge holders to knowledge users.

2-Reservoir models which use information technology to acquire, organize, store, and distribute objective organizational knowledge.

Hansen et al. state that there are at least two strategies for knowledge management: codification strategy and personalization strategy (25). Encoding strategy is concerned with organization whose competitive advantage stems from re-application of encoding knowledge and emphasizes on the creation of researchable reservoirs for the storage and retrieval of encoded knowledge (26).

Personalization processing style stimulates knowledge learning and creation through collective interaction with experts and colleagues. Based on the latter strategy, knowledge is formed not only through face-to-face interaction but also through electronic communications such as networks of individual (27). Today, networks are considerably used for knowledge interaction and scientific research. Fluid and network-based technologies are used in social media in order to create dynamic backgrounds through which people can share and recreate produced contents (28). Arntzan et al. (29) emphasized on proper and effective use of information technologies in universities for improving knowledge-based organizational learning and web technologies like social networks, wikis, and blogs for supporting knowledge management plans. The study by Ulka et al. (30) highlighted the important role of information and communication technologies in relieving dominant challenges of technology and knowledge sharing, exchange and expansion in higher education. The study by Jones et al. (31) focused on the development of an online portal for linking academic researchers in order to fill in the gap of sharing and knowledge accessibility by using management methods. Meatal's research (32) indicates the impact of information systems on academic staff's scientific activities and the role of information technology on knowledge management and value production. Adhikari (33) viewed the lack of technological thought formation as the most important challenge in universities. Sveiby and Simons (34) expressed that a cooperative atmosphere is the main factor in the process of knowledge creation. According to Liebeskind et al. (35), social networks act better than organizational arrangements in providing knowledge resources in universities.

The present study aims to identify effective factors in optimal use of information and communication technology for academic staff's knowledge management in higher education.

\section{Methods}

The present research is conducted by following a qualitative approach and using content analysis method across state universities in Tehran. As is generally agreed, content analysis is widely used for defining certain concepts and words in a text or a set of texts. A text includes books, chapter(s) of a book writings, interviews, talks, titles, newspaper headlines, and historic documents. A researcher used the content analysis method to analyze the existence of concepts or relations between words or concepts (36). Data collection method includes semi-structured interviews with scholars and academic experts are conducted by the objective method. In this method, a researcher chooses samples which suit her (his) stated goals and data collection process continues until a theoretical saturation is reached (37). Thus, a sample which could provide the most information on the research area was chosen among academic staff members of state universities in Tehran. These members were engaged in the field of knowledge management and had been awarded as associate professors or professors in the year 2016. Table 1 shows some features of scholars and staff members who participated in interviews.

\begin{tabular}{|c|c|}
\hline Scientific Ranking & Academic Staff Member \\
\hline Professor & Tarbiyat modarres university \\
\hline Professor & Tehran university \\
\hline Professor & Payam-e-noor university \\
\hline Associate professor & Tarbiyat modarres university \\
\hline Associate professor & Tehran university \\
\hline Associate professor & Shahid beheshti university \\
\hline Associate professor & Payam-e-noor university \\
\hline
\end{tabular}

Interviews continued until different effective aspects 
and factors of information and communication technology on knowledge management for academic staff member were identified and described. Our sample was chosen in an objective method for the following reasons:

1) Both the expertise and knowledge of university and research scholars and educational institutes' teachers could be benefited from simultaneously.

2) Those selected for the sample had long been involved in research and scientific activities so that they had adequate knowledge of research subject and, also, had publications in this area. Main ideas of semi-structured and individual interviews with scholars were determined after research background and theoretical bases had been studied. As the findings of our study, main and additional effective factors of knowledge management were identified.

All the interviews were done individually and later were transcribed. Each interview lasted between 60 and 90 minutes. For ethical considerations, interviews were done after receiving voluntary consents from participants. In addition, participants could leave interviews when desired. Interviewees were assured that names and contents of interviews were kept confidential. After having gathered necessary qualitative data, main and additional categories were derived from open and axial encoding processes on resulting data from detailed interviews with key scholars. The priority of each factor was determined based on the frequency of mentioned content analysis used. In order to analyze data carefully, concepts were studied through encoding, direct transcription of interviews with key scholars, and analyzing documents line by line. They were then analyzed into statements and expressions which are called raw data. After that collected sentences and expressions were continuously compared and classified into similar sentences and expressions. Next, concept (s), which was referred to in texts, was extracted. In order to ensure that all concepts are extracted, sentences and expressions were studied and compared from the beginning to the end of the texts. After common conceptual codes were extracted and repetitive instances were removed, theoretical bases were used to compare conceptual codes and to identify concepts. Finally, main and additional categories were research processes which are given in Figure 1.

To make sure that our research is reliable and results are accurate, we went through the following stages: (38) at first, results were examined by the participants in the interviews. They reviewed categories and commented on them. Secondly, research advisors and supervisors examined findings and expressed their opinions.

\section{Results}

For the purpose of our study, effective factors on the optimal use of information and communication technology for academic staff members' knowledge management in higher education were identified by analyzing data from semi-structured interviews and reviewing research background. It should be noted that data were classified and encoded after semi structured interviews. In the following, each factor is explained in Tables 2 and 3.

Table 2. the Main and Additional Concepts Expressed by Scholars About Effective Technological Factors on the Management of Knowledge

\begin{tabular}{|c|c|}
\hline Main Themes & Additional Themes \\
\hline Hardware infrastructure & $\begin{array}{l}\text { 1. Updated hardware infrastructure, } 2 \text {. Support from } \\
\text { hardware systems, 3. Website design and update, } 4 . \\
\text { Communicative infrastructure development, } 5 \text {. } \\
\text { Internet network support, } 6 \text {. Financial support for } \\
\text { purchasing, } 7 \text {. Equipped universities with } \\
\text { communicative and information technology tools. }\end{array}$ \\
\hline Necessary software & $\begin{array}{l}\text { 1. The development of support hardware; } 2 \text {. Updated } \\
\text { software; } 3 \text {. Necessary software maintenance; } 4 \text {. } \\
\text { Interactive software on web; } 5 \text {. Groupware; } 6 \text {. } \\
\text { Interactive tools and multi-channel programs. }\end{array}$ \\
\hline Access to university and academic databases & $\begin{array}{l}\text { 1. Access to information resources; } 2 \text {. Online access to } \\
\text { university and academic databases; } 3 \text {. Electronic } \\
\text { libraries; } 4 \text {. Knowledge banks; } 5 \text {. Knowledge maps }\end{array}$ \\
\hline Electronic knowledge networks & $\begin{array}{l}\text { 1. The creation of a knowledge network for identifying } \\
\text { experts; } 2 \text {. A knowledge network and increased } \\
\text { cooperation and collaboration for knowledge } \\
\text { production; } 3 \text {. A knowledge network and knowledge } \\
\text { exchange and relations between academic staff } \\
\text { members; } 4 \text {. A knowledge network and quick and easy } \\
\text { exchange and transfer of information between } \\
\text { universities and research centers; } 5 \text {. A knowledge } \\
\text { network, virtual communications and online chat } \\
\text { rooms }\end{array}$ \\
\hline Access to new technologies & $\begin{array}{l}\text { 1. Technology for easier access to information } \\
\text { resources; } 2 \text {. Technology as a facilitator of knowledge } \\
\text { creation; } 3 \text {. Knowledge exchange technology and } \\
\text { facilitator of team work; } 4 \text {. Related technology to } \\
\text { storage and retrieval; } 5 \text {. Technology for integration, } \\
\text { filing, and the transfer of knowledge. }\end{array}$ \\
\hline Mastery over related software & $\begin{array}{l}\text { 1. Updating academic staff members' skills in using } \\
\text { technologies; } 2 \text {. Teaching how to use communicative } \\
\text { information technologies; } 3 \text {. Increasing informational } \\
\text { literacy; } 4 \text {. Acquiring new skills in the fields of } \\
\text { information technology and required software }\end{array}$ \\
\hline
\end{tabular}

Results from encoding and categorical content analysis showed that 6 categories or factors of communication and information technology are highly important in state universities. In table 3, the frequency and samples of interviews will be brought along with interviewee codes. Because of the high volume of interviews, one or two interviews are mentioned for each category.

Hardware infrastructures: As can be seen from the first row of open encoding table, hardware infrastructure was highlighted by all scholars for knowledge support, exchange, organization, and application. Here are some quotes from scholars: "one of the effective factors of knowledge management is the use of updated hardware infrastructures for supporting activities related to knowledge management", "support from hardware systems, internal network, internet, website design, and updated website in- 


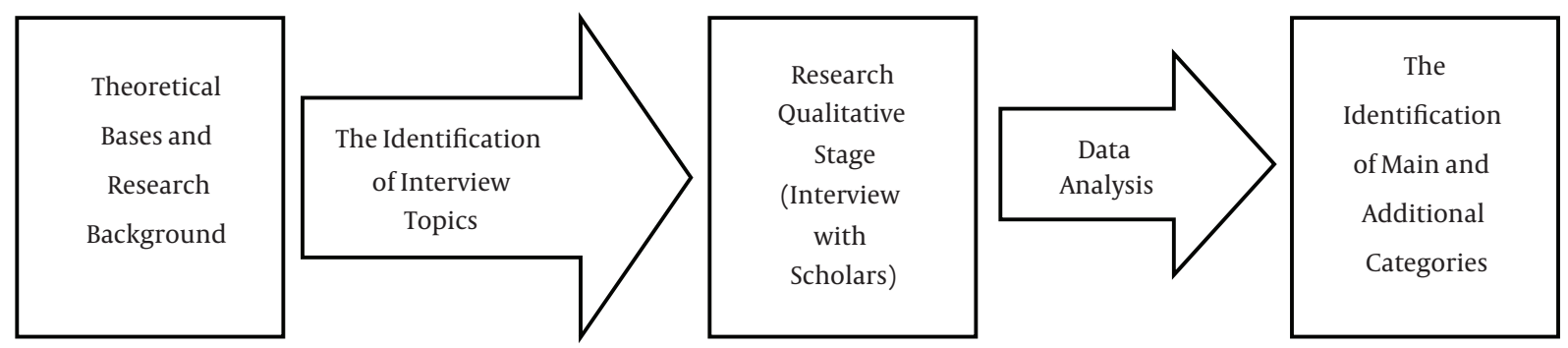

Figure 1. A General Schematic of Research Method

fluence the knowledge creation by academic staff members".

Applied software: results from information analysis of interviews indicates that all scholars agree that necessary software are important for supporting knowledge creation, exchange, organization, and application. As stated by one of the scholars: "given the important role of information technology in knowledge management, modern and useful software should be broadened to facilitate and accelerate knowledge management processes". Another scholar focused on updating software for knowledge management.

Access to university and academic databases: the main purpose of higher education is to grow and develop researches in universities and higher education institutions. Communication and information technology play a vital part in this respect. As is seen in the third row of open encoding table, online access to university and academic informational platforms and the use of the latest scientific information are effective on knowledge creation.

Electronic knowledge networks: the 4th row in the encoding column suggests that electronic knowledge networks are one main indicator of knowledge creation, exchange, and sharing. Knowledge networks are a suitable tool for connecting scholars and experts within organizations in order to exchange knowledge. The following statements show how much scholars emphasize on the importance of this element: "electronic knowledge networks make it possible to identify specialized people to share and exchange knowledge", "by connecting academic staff members who have common scientific interests but are geographically scattered, knowledge networks enable quick and easy information exchange and knowledge transfer among research and academic centers." Other scholars remarked that communication and information technology facilitates cooperation with other academic staff members whose knowledge is important to them. "Or" networks enable scientific actors to accumulate their knowledge in order to gain superior knowledge in their fields of interest and to avoid overlapping measures.

Access to new technologies: the 5th rows of encoding column show the significance of access to new technologies for knowledge search, storage, retrieval, exchange, and processing. Scholars expressed that new technologies have facilitated and accelerated information indexing, integration, filing and sharing, "technologies related to knowledge retrieval and storage are known as a revolution in organizing and expanding information", "communication technologies enable users to access required knowledge, especially for experts", "technologies which facilitate teamwork and software which connect scholars provide the opportunities for content sharing, cooperation, interaction, and relationship across the world".

Mastery over related software: the last row of encoding column is mastery over related software.

According to scholars, communication and information technology cannot facilitate knowledge orientation process in organization, but instead is a very important factor of recognition, awareness, and individuals' ability in using these technologies.

In this regard, scholars stated that "given the rapid development of communication and information technology, updated specialized skills in using technology influence the application of technologies", "powerful human capital in universities is the main factor of knowledge creation within organizations", "mastery over related software can positively influence knowledge management", "universities need to provide educational courses on new skills of information technology".

As mentioned above, after collecting data from semistructured interviews, we initiated qualitative data analysis process. Later, data were filtered and encoded based on research subjects. After encoding, redundant data were removed and data were filtered. Finally, categories which objectively represent a more general category were aligned and classified into 6 factors of communication and information technology related to knowledge management in higher education. These categories include supporting 
hardware and software infrastructures, access to university and academic databases, electronic knowledge networks, access to new technologies for knowledge search, storage, retrieval, exchange, and processing and, lastly, mastery over related software. The final product of semistructured interviews with scholars were shown in Figure 2.

\section{Discussion}

The primary purpose of the present paper was to identify those factors of communication and information technology which are related to knowledge management in higher education.

Results from the study suggest that supporting hardware and software infrastructures, access to university and academic databases, electronic knowledge networks, access to new technologies for search, retrieval, storage, exchange and processing of knowledge, and mastery over related software are known as the most important and effective factors of communication and information technology on the knowledge management of academic staff members. Below, each factor will be discussed and compared. Results from our study suggest that academic scholars regard hardware infrastructures as one of the most effective factors on the knowledge management of academic staff members because every single communication and information technology program must be implemented on the grounds of sound and rigid infrastructures. Thus investments on infrastructures should be done regarding their importance as the main drive and key infrastructures of the development of communication and information technology in universities. This result is consistent with the results from pang et al. (5) and photo (39) on the importance of infrastructures on optimal knowledge management.

According to our findings, another effective factor on the knowledge management of academic staff members in universities is the importance of necessary software for supporting knowledge creation, exchange, organization, and application.

In this respect, modern useful software which facilitate and accelerate knowledge management processes should be expanded. This finding is also consistent with studies conducted by Kang et al. (40), which had emphasized on the importance of suitable communicative systems for knowledge transfer and sharing, our finding is, also, consistent with studies by Boughzala and Dudezert (41) and Kietzmann et al. (28) on the importance of social software in knowledge sharing.

As is derived from the results, a key indicator of knowledge management is using electronic knowledge networks for knowledge creation, exchange, and sharing with colleagues. Knowledge networks are the tools which link experts and scholars within organization in order to exchange knowledge and eventually achieve their desired goals. Majority of scholars agreed that cooperation and participation in academic activities are the key factors of academic staff members' empowerment. This implies that the development and improvement of knowledge management depend on the improvement of communication and interactions among academic staff members.

This finding is confirmed by Nory B.Jones et al.'s study on linking academic researchers for filling the existing gaps of knowledge sharing and accessibility in universities (31); it is also supported by studies led by Sveiby and Simons (34) on cooperation atmosphere and knowledge creation and Orlikoski (42) on the positive role of communication networks in more effective cooperation among academic staff members. Yong and Wan (43) stated that social interactions are centered around interpersonal behavioral interactions, value sharing and transfer, assumptions, attitudes, and recognition.

They believed that social interactions rely on informal gatherings, discourses, social events, collaborative thoughts, networks and consultation plans. Nealson used the concept of knowledge embedment to explain the role of communications in knowledge creation process (10). Thus, members, in knowledge networks, converge from distant geographical locations with the help of communication technologies and information enters networks from every corner of the world. Networks link members in both real and virtual manners and create a suitable background for the production of knowledge. Knowledge management in networks depends on cooperation, collaboration, and teamwork skills.

They become possible through knowledge socialization and the conversion of tacit knowledge into explicit knowledge. Networks play a big part in linking individual and forming academic coalition and unions and eventually knowledge creation (42).

The 5 th rows in encoding column necessitate access to modern technologies for knowledge search, retrieval, exchange, and processing. According to scholars, technology opens the way into empowerment and the expansion of interactions among groups and organizations. It enables individuals to overcome the limitations of time and space. Besides, it expands the area and depth of access to information as well as facilitating knowledge creation, exchange, and sharing. Scholars clearly stated that those technologies which facilitate teamwork and software which link scholars provide opportunities for cooperation, interaction, relationship, and sharing of contents of any kind. It should be emphasized that information technology acts 


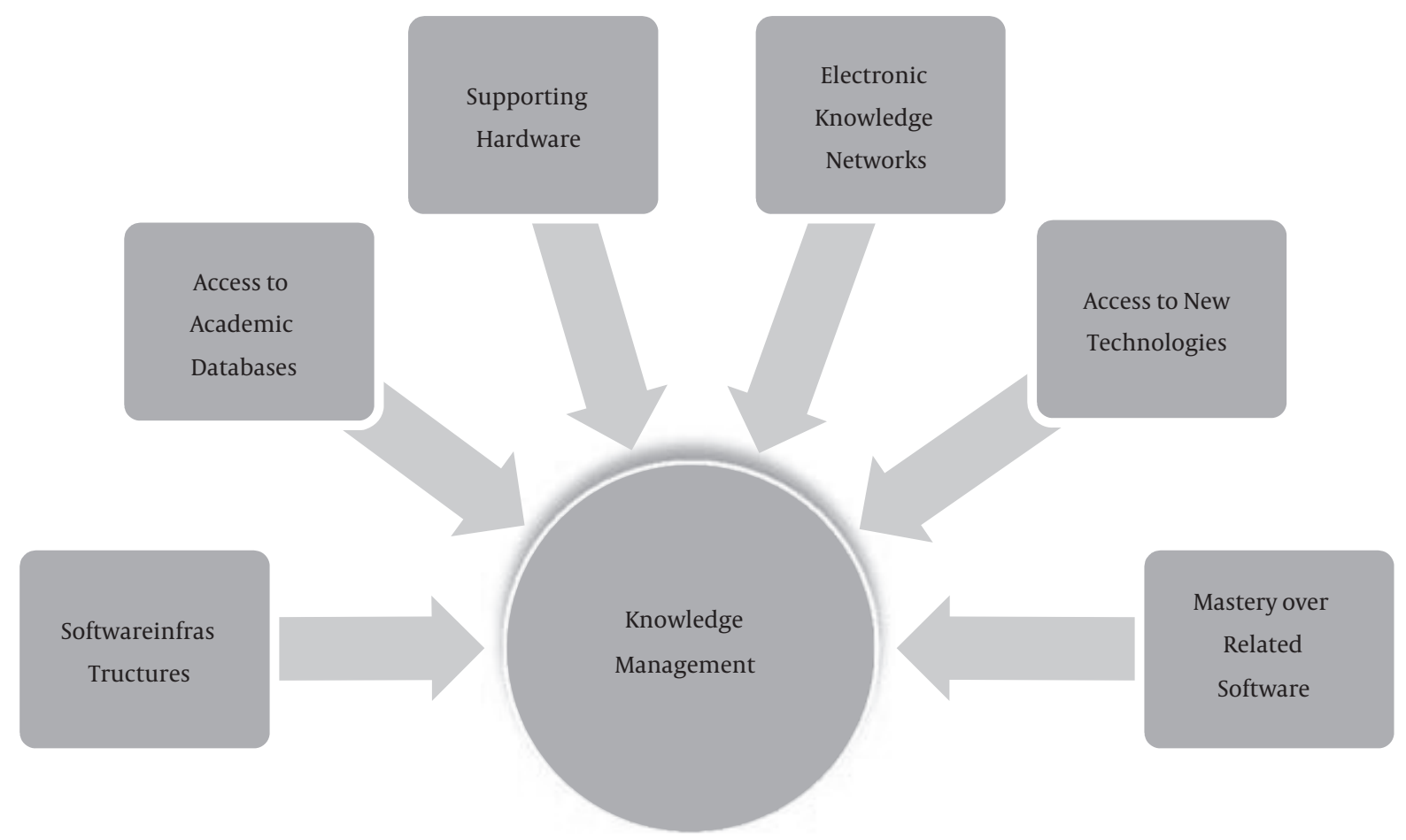

Figure 2. Factors of ICT Related to Knowledge Management in Higher Education

as a supporter of knowledge management and helps individuals gain suitable information. Communication technologies enable users to access their desired knowledge and communicate with each other, particularly with experts, collaboration technologies provide necessary conditions for teamwork. For instance users are able to work on shared documents both simultaneously and at different times. This is of particular value for interactive group members who have an important role in knowledge production (1). This finding is supported by several others.

Researchers: Artzen et al. (29) on the importance of effective and useful application of information technologies in universities for improving knowledge-based organizational learning and web technologies such as wikis, blogs, social networks and so on for supporting knowledge management plans; Ulka (30) on the important role of communication and information technology in relieving dominant challenges of knowledge and technology sharing an exchange in higher education; $M i t t e l(32)$ on the positive role of information systems in scientific activities by academic staff members and the influence of information technology on value production and knowledge management; Kulakl and Mahony (44) on the importance of technology in knowledge management. According to Zwari et al. (45), the shortage of communication and information technology which represents a technical problem, hinders knowledge sharing.

The last row of encoding column is concerned with mastery over related software. Almost all scholars claimed that communication and information technology cannot facilitate knowledge orientation process in organization by itself. Instead, individuals need to have acquired underlying recognition and abilities of applying those technologic. As far as technological infrastructures are concerned, rapid development of communication and information technologies, as well as fear from inability to use them make individuals unwilling to improve their specialized skills, thereby they will lose their contact with their surrounding communication and information technology. Training contributes to the knowledge management process as well as knowledge creation, storage, transfer, sharing, and application within organization $(46,47)$. Therefore, the first step to the application of technology is to teach how to use communication and information technological software.

We developed a conceptual framework for studying knowledge management process in academies and policy making in this field. In order to apply the findings of our 
Table 3. Encoding Qualitative Data from Semi-Structured Interviews

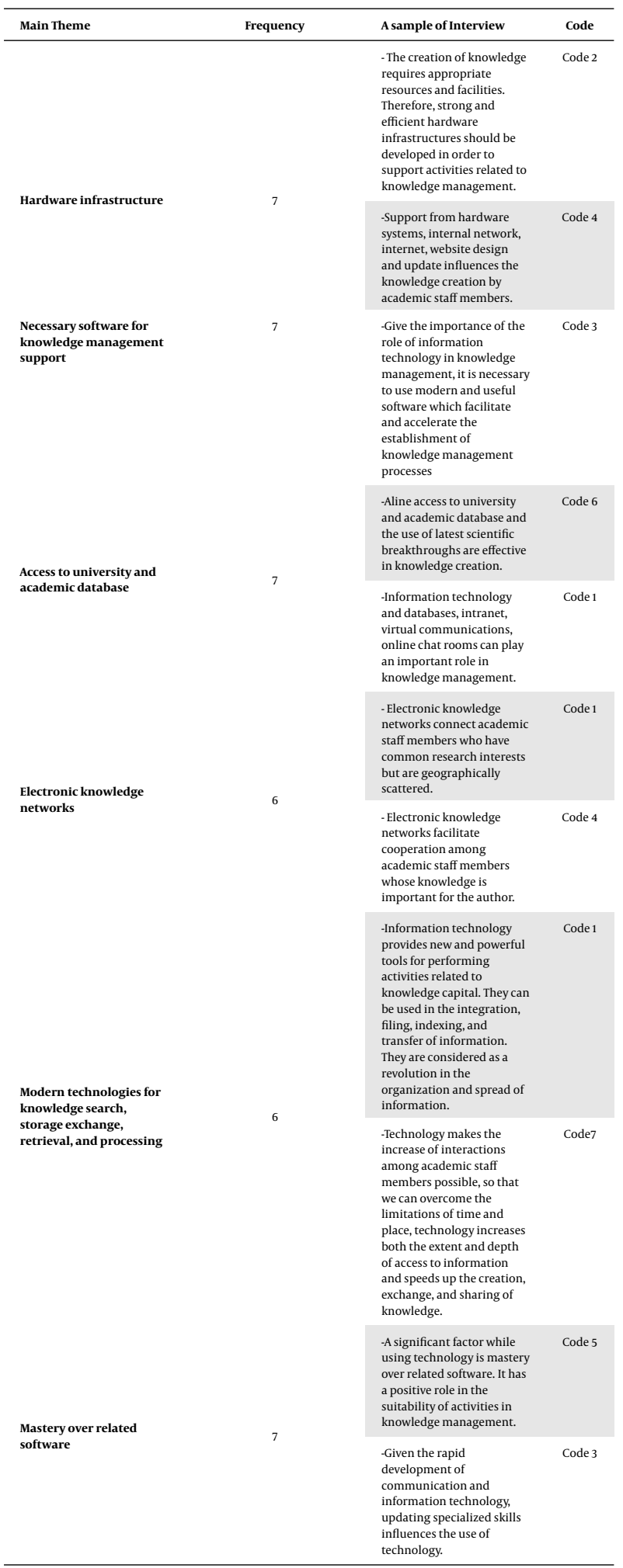

research in practice, with a decision-making outlook and efficient development of knowledge management among academic staff member, the establishment of knowledge management system approach should be focused by senior managers of universities:

- Developing appropriate and updated hardware and software infrastructures based on the latest existing technologies.

- Developing communication facilities such as electronic knowledge networks in order to recognize researchers in other academic centers and to share and exchange knowledge.

- Developing data platforms and providing access to modern academic resources for staff members.

Given the indisputable role of information technology in knowledge creation, managers need to develop technologies and modern software which contribute to the establishment of knowledge management processes.

Regarding the importance and influence of modern technologies on knowledge management, we suggest that academic staff members should be trained about related technologies and updating their specialized skills in using those technologies.

\section{References}

1. Tian J, Tsui E, Nakamori Y, Wierzbicki AP. Knowledge management and knowledge creation in academia: a study based on surveys in a Japanese research university. J Knowledge Manag. 2009;13(2):76-92. doi: 10.1108/13673270910942718.

2. Pangil F, Moi Chan J. The mediating effect of knowledge sharing on the relationship between trust and virtual team effectiveness.J Knowledge Manag. 2014;18(1):92-106. doi:10.1108/jkm-09-2013-0341.

3. Iniesta-Bonillo MA, Sánchez-Fernandez R, Schlesinger W. Investigating factors that influence on ICT usage in higher education: a descriptive analysis. Int Rev Public Nonprofit Market. 2013;10(2):163-74. doi: 10.1007/s12208-013-0095-7.

4. Songsangyos P. The Knowledge Management in Higher Education in Chiang Mai: A Comparative Review. Proc Soc Behav Sci. 2012;69:399403. doi: 10.1016/j.sbspro.2012.11.426.

5. Peng J, Jiang D, Zhang X. Design and Implement a Knowledge Management System to Support Web-based Learning in Higher Education. Proc Comput Sci. 2013;22:95-103. doi: 10.1016/j.procs.2013.09.085.

6. McCarthy AF. Knowledge management: Evaluating strategies and processes used in higher education. ; 2006.

7. Fullwood R, Rowley J, Delbridge R. Knowledge sharing amongst academics in UK universities. J Knowledge Manag. 2013;17(1):123-36. doi: $10.1108 / 13673271311300831$.

8. Mabey C, Nicholds A. Discourses of knowledge across global networks: What can be learnt about knowledge leadership from the ATLAS collaboration? Int Business Rev. 2015;24(1):43-54. doi: 10.1016/j.ibusrev.2014.05.007.

9. Laal M. Knowledge management in higher education. Proc Comput Sci. 2011;3:544-9. doi: 10.1016/j.procs.2010.12.090.

10. Jain P, Kelvin Joseph B. Knowledge management portals as enablers for institutional competitiveness: Surveying universities in Southern African Development Community (SADC). J Inf Knowledge Manag Systems. 2013;43(4):400-23. 
11. Wild R, Griggs K. A model of information technology opportunities for facilitating the practice of knowledge management. Vine. 2008;38(4):490-506. doi: 10.1108/03055720810917732.

12. Nonaka I, Toyama R, Konno N. SECI, Ba and Leadership: a Unified Model of Dynamic Knowledge Creation. Long Range Plann. 2000;33(1):5-34. doi:10.1016/s0024-6301(99)00115-6.

13. Jashapara A. Knowledge management: An integrated approach. Pearson Education; 2004.

14. Wen Chong C, Holden T, Wilhelmij P, Schmidt RA. Where does knowledge management add value? J Intellect Capital. 2000;1(4):366-80. doi: $10.1108 / 14691930010359261$.

15. Coakes E, Amar AD, Luisa Granados M. Knowledge management, strategy, and technology: a global snapshot. J Enterprise Inf Manag. 2010;23(3):282-304. doi:10.1108/17410391011036076.

16. Palvalin M, Lönnqvist A, Vuolle M. Analysing the impacts of ICT on knowledge work productivity. J Knowledge Manag. 2013;17(4):545-57.

17. Skyrme D, Amidon D. The Knowledge Agenda. J Knowledge Manag. 1997;1(1):27-37. doi: 10.1108/13673279710800709.

18. Holsapple CW, Joshi KD. An investigation of factors that influence the management of knowledge in organizations. J Strateg Inf Systems. 2000;9(2-3):235-61. doi:10.1016/s0963-8687(00)00046-9.

19. Guzman G, Trivelato LF. Packaging and unpackaging knowledge in mass higher education-a knowledge management perspective. High Educ. 2010;62(4):451-65. doi: 10.1007/s10734-010-9398-3.

20. Duffy J. Knowledge management: What every information professional should know. Inf Manag. 2000;34(3):10.

21. Metaxiotis K, Psarras J, Papastefanatos S. Knowledge and information management in e-learning environments; the user agent architecture. Inf Manag Comput Secur. 2002;10(4):165-70. doi: $10.1108 / 09685220210436958$.

22. Mathiassen L, Pourkomeylian P. Managing knowledge in a software organization. I Knowledge Manag. 2003;7(2):63-80. doi: $10.1108 / 13673270310477298$.

23. Dalkir K, Liebowitz J. Knowledge management in theory and practice. MIT press; 2011.

24. Gottschalk P. Strategic knowledge management technology. Macmillan; 2005.

25. King WR. Knowledge Management and Organizational Learning. 4. Springer; 2009.

26. Hislop D. Knowledge management in organizations: A critical introduction. Oxford University Press; 2013.

27. Sherif K. An adaptive strategy for managing knowledge in organizations. J Knowledge Manag. 2006;10(4):72-80. doi: $10.1108 / 13673270610679372$.

28. Kietzmann JH, Silvestre BS, McCarthy IP, Pitt LF. Unpacking the social media phenomenon: towards a research agenda.J Public Affairs. 2012;12(2):109-19. doi: 10.1002/pa.1412.

29. Aurelie Bechina Arntzen A, Tsui E, Worasinchai L, Ribière VM. An insight into knowledge management practices at Bangkok University.
Knowledge Manag. 2009;13(2):127-44. doi:10.1108/13673270910942745

30. Toro U, Joshi MJ. A review of literature on knowledge management using ICT in higher education. Int J Comput Technol Appl. 2013;4(1):62.

31. Jones NB, Provost DM, Pascale D. Developing a university research web-based knowledge portal. Int J Knowledge Learn. 2006;2(1/2):106 doi: 10.1504/ijkl.2006.009682.

32. Mittal M. Personal Knowledge Management: A Study of Knowledge Behaviour of Academicians. J Inf Knowledge Manag. 2008;07(02):93100. doi: $10.1142 / s 0219649208001993$.

33. Raj Adhikari D. Knowledge management in academic institutions. Int JEduc Manag. 2010;24(2):94-104. doi:10.1108/09513541011020918.

34. Sveiby KE, Simons R. Collaborative climate and effectiveness of knowledge work - an empirical study.J Knowledge Manag. 2002;6(5):420-33. doi: 10.1108/13673270210450388.

35. Liebeskind JP, Oliver AL, Zucker L, Brewer M. Social networks, Learning, and Flexibility: Sourcing Scientific Knowledge in New Biotechnology Firms. Organiz Sci. 1996;7(4):428-43. doi: 10.1287/orsc.7.4.428.

36. Zeighami R, Nesami MB, Oskouie F, Nikravesh MY. Content analysis. Iran J Nurs. 2008;21(53):41-52.

37. Heyvaert M, Maes B, Onghena P. Mixed methods research synthesis: definition, framework, and potential. Qual Quant. 2011;47(2):659-76. doi: 10.1007/s11135-011-9538-6.

38. Creswell JW, Miller DL. Determining Validity in Qualitative Inquiry Theory Into Pract. 2000;39(3):124-30. doi:10.1207/s15430421tip3903_2.

39. Foote AR. Exploring knowledge management models on information technology (IT) projects. Walden University; 2016.

40. Kang YJ, Kim SE, Chang GW. The Impact of Knowledge Sharing on Work Performance: An Empirical Analysis of the Public Employees Perceptions in South Korea. Int J Public Administ. 2008;31(14):1548-68. doi: $10.1080 / 01900690802243607$.

41. Boughzala I, Dudezert A. Knowledge Management 2.0: Organizational Models and Enterprise Strategies. IGI Global; 2012.

42. Orlikowski WJ, Yates J, Okamura K, Fujimoto M. Shaping Electronic Communication: The Metastructuring of Technology in the Context of Use. Organiz Sci. 1995;6(4):423-44. doi:10.1287/orsc.6.4.423.

43. Yang JT, Wan CS. Advancing organizational effectiveness and knowledge management implementation. Tourism Manag. 2004;25(5):593601. doi: 10.1016/j.tourman.2003.08.002.

44. Kulakli A, Mahony S. Knowledge Creation and Sharing with Web 2.0 Tools for Teaching and Learning Roles in So-called University 2.0. Proc Soc Behav Sci. 2014;150:648-57. doi:10.1016/j.sbspro.2014.09.084.

45. Zawawi AA, Zakaria Z, Kamarunzaman NZ, Noordin N, Sawal MZHM, Junos NM, et al. The study of barrier factors in knowledge sharing: A case study in public university. Manag Sci Engin. 2011;5(1):59.

46. Alderbesti K. A comparative study: The effect of strategic alliances on knowledge creation capabilities and organizational climate measures. George Washington University; 2003.

47. Abtahi SH, Kheirandish M. Knowledge management with organizational Context approach. Tehran: Modiran Emrouz; 2015. 